\title{
Aggressive hemangioma of the spine in a pregnant female: a case report and literature review
}

\author{
Gebe bir kadında omurganın agresif hemanjiomu: Olgu sunumu ve literatür taraması
}

\author{
İsmail Demirkale, MD., ${ }^{1}$ Federico De lure, MD., ${ }^{2}$ Silvia Terzi, MD., ${ }^{3}$ Alessandro Gasbarrini, MD. ${ }^{3}$ \\ 1Department of Orthopedics and Traumatology, Keçiören Training and Research Hospital, Ankara, Turkey \\ ${ }^{2}$ Ospedale Maggiore, Bologna, Italy \\ ${ }^{3}$ Instituto Ortopedico Rizzoli, Bologna, Italy
}

\begin{abstract}
Type and timing of treatment for symptomatic hemangiomas in pregnant females are challenging due to fetus survival and conflicts in neurological recovery. In this article, we report a 40-year-old female patient at pregnancy week 23 with a complicated hemangioma at $\mathrm{T}_{1}$ level. Physical examination revealed an incomplete spastic paraplegia. Patient did not accept any surgery due to child's death risk. Patient was started corticoid treatment and no more weight bearing was allowed. At the $28^{\text {th }}$ week of pregnancy, the patient underwent cesarean section immediately followed by selective arterial embolization, decompression, fixation, and radiotherapy. At two-year follow-up, the patient was pain free, without any signs of local recurrence and with complete neurological recovery. A multidisciplinary approach is mandatory to save the life of the fetus without damaging the spinal cord functions of the mother.
\end{abstract}

Keywords: Hemangioma; paraplegia; pregnancy; spine.

Vertebral hemangiomas can become symptomatic in pregnancy. Review of the literature for vertebral body hemangiomas in pregnancy revealed 23 cases in 21 case reports leading to neurological deterioration (Table I). ${ }^{[1-21]}$ Time from onset of symptoms to intervention had a wide variation, from two days to six months. Emergency care can be easily undertaken in these patients; however, some challenges emerge when the patient is at the second term. In this article, we report a paradigmatic case of a pregnant female with multiple challenges. ${ }^{[22]}$
$\ddot{O} Z$

Gebe kadınlarda semptomatik hemanjiomların tedavi tipi ve zamanlaması fetüsün yaşaması ve nörolojik düzelmedeki tartışmalar nedeniyle zordur. Bu yazıda, $\mathrm{T}_{1}$ seviyesinde komplike olmuş hemanjioması ve gebeliğinin 23. haftasında olan 40 yaşında bir kadın hasta sunuldu. Fizik muayenede inkomplet spastik parapleji görüldü. Hasta, çocuğun ölüm riski nedeniyle hiçbir ameliyatı kabul etmedi. Hastada kortikoid tedavisine başlandı ve daha fazla ağırlık taşımasına izin verilmedi. Gebeliğin 28. haftasında hastanın sezaryen ile doğumu gerçekleştirildi; takiben selektif arteriyel embolizasyon, dekompresyon, fiksasyon ve radyoterapi uyguland. İki yıllık takibinde hasta herhangi bir lokal nüks olmaksızın ve tam nörolojik iyileşme ile ağrısızdı. Annenin spinal kord fonksiyonlarını bozmadan çocuğun hayatını kurtarmak için multidisipliner bir yaklaşım şarttır.

Anahtar sözcükler: Hemanjiom; parapleji; gebelik; omurga.

\section{CASE REPORT}

A 40-year-old pregnant female patient was referred to the emergency room at the $23^{\text {th }}$ week of gestation with cervicothoracic pain and gradually increasing weakness at lower limbs that started three weeks before. The patient was unable to walk and there was a sensory loss up to the shoulders. The motor examination revealed spastic incomplete paraplegia with proximally $2 / 5$ and distally $4 / 5$ motor strength in both legs. Babinski test was bilaterally positive,

- Received: June 24, 2015 Accepted: July 29, 2015

- Correspondence: İsmail Demirkale, MD. Keçiören Eğitim ve Araştırma Hastanesi Ortopedi ve Travmatoloji Kliniği, 06280 Keçiören, Ankara, Turkey. Tel: +90 505 - 4002679 Fax: +90 312 - 3569027 e-mail: drismail@yahoo.com 
TABLE I

Systematic review of the literature for complicated vertebral body hemangiomas in pregnancy

\begin{tabular}{|c|c|c|c|c|}
\hline Authors & Gestation & Level & Duration of symptoms & Recovery \\
\hline Guthkelch $^{[21]}$ & 34 & $\mathrm{~T}_{6}$ & 1 month & Death \\
\hline Askenasy and Behmoaram ${ }^{[20]}$ & 34 & $\mathrm{~T}_{10}$ & 15 days & Complete \\
\hline Fields and Jones ${ }^{[19]}$ & 28 & $\mathrm{~T}_{10}$ & 3 months & Complete \\
\hline Newman $^{[18]}$ & 32 & $\mathrm{~L}_{3}$ & 8 months & Complete \\
\hline Newman $^{[18]}$ & 36 & $\mathrm{~T}_{4}$ & 1 month & Complete \\
\hline Newman $^{[18]}$ & 32 & $\mathrm{~T}_{4-5}$ & 3 months & Death \\
\hline Nelson ${ }^{[17]}$ & 28 & $\mathrm{~T}_{2-4}$ & 1 month & Partial \\
\hline Esparza et al..$^{[16]}$ & 24 & $T_{5-7}$ & 2 months & Complete \\
\hline Faria et al. ${ }^{[15]}$ & 32 & $\mathrm{~T}_{4}$ & 6 months & Complete \\
\hline Lavi et al. ${ }^{[14]}$ & 28 & $\mathrm{~T}_{4-6}$ & 1 month & Partial \\
\hline Schwartz et al. ${ }^{[13]}$ & 30 & $\mathrm{~T}_{5}$ & 1 month & Complete \\
\hline Liu and Yang ${ }^{[12]}$ & 20 & $\mathrm{~T}_{4}$ & 1 month & Complete \\
\hline Redekop and Del Maestro ${ }^{[11]}$ & 32 & $\mathrm{~T}_{12}$ & 4 months & Partial \\
\hline Tekkök et al..[2] & Po & $\mathrm{T}_{5}$ & 40 days & Complete \\
\hline Castel et al..$^{[5]}$ & 28 & $\mathrm{~T}_{8}$ & few days & Partial \\
\hline Chi et al. ${ }^{[4]}$ & 24 & $\mathrm{C}_{7}$ & 25 days & Partial \\
\hline Inamasu et al. ${ }^{[6]}$ & 33 & $\mathrm{~L}_{2}$ & 10 days & Complete \\
\hline Yüksel et al. ${ }^{[9]}$ & 28 & $\mathrm{~T}_{9}$ & 2 months & Complete \\
\hline Vijay et al. ${ }^{[7]}$ & 26 & $\mathrm{~T}_{11}$ & 8 days & Complete \\
\hline Kiroglu et al. ${ }^{[8]}$ & 36 & $\mathrm{~T}_{4}$ & few days & Complete \\
\hline Schwartz et al. ${ }^{[3]}$ & Po & $\mathrm{T}_{11}$ & 2 days & Complete \\
\hline Shinozaki et al. ${ }^{[10]}$ & 28 & $\mathrm{~T}_{2}$ & few days & Complete \\
\hline Blecher et al. ${ }^{[27]}$ & 37 & $\mathrm{~L}_{4}$ & several weeks & Complete \\
\hline Present case & 23 & $\mathrm{~T}_{1}$ & 8 weeks & Complete \\
\hline
\end{tabular}

Duration of symptoms: Time from onset of symptoms and operative intervention; Po: Postpartum.

there was mild clonus on both legs and both knee jerk and Achilles reflexes were bilaterally exaggerated. The examination of the upper extremity exhibited $4 / 5$ motor strength at the left interosseous muscles. Computed tomography (Figure 1) with threedimensional reconstruction (Figure 2) and magnetic resonance imaging (Figure 3) were obtained. Computed tomography showed honeycomb pattern involving entire $T_{1}$ vertebra strongly suggestive for hemangioma. A written informed consent was obtained from the patient.

On admission, emergency surgical decompression was proposed to the patient, immediately after interruption of the pregnancy. The patient refused interruption of pregnancy and any other treatment possibly creating high risk for the fetus survival. She was alerted of the risk of worsening of neurological conditions and irreversible paraplegia.
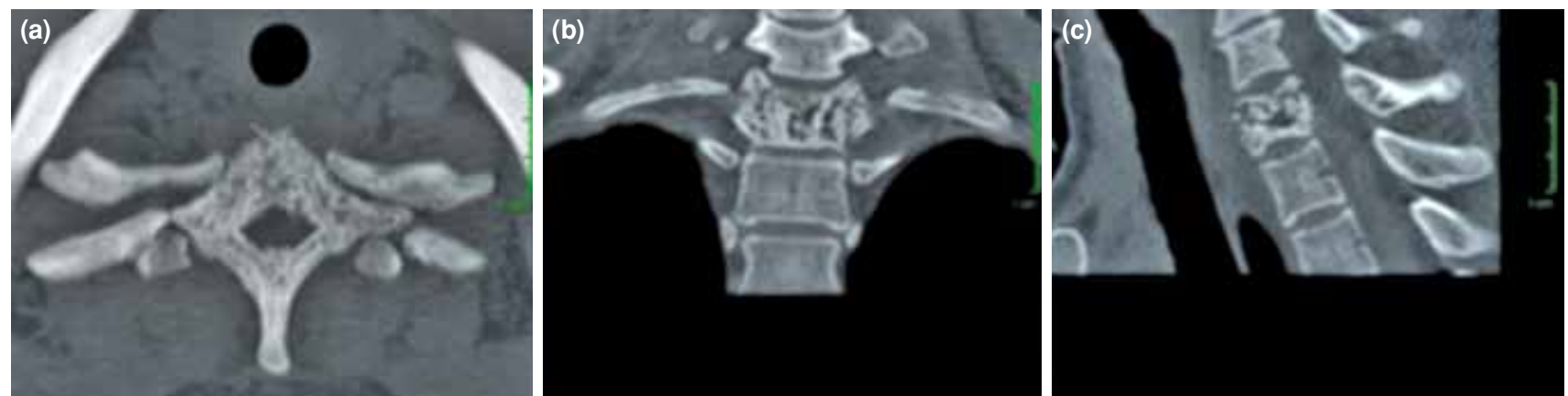

Figure 1. (a) Axial, (b) coronal, and (c) sagittal computed tomography sections of $T_{1}$ vertebra show classical appearance of a hemangioma with vertical striations and honeycomb pattern involving both corpus and posterior neural $\operatorname{arch}$ of $T_{1}$. 

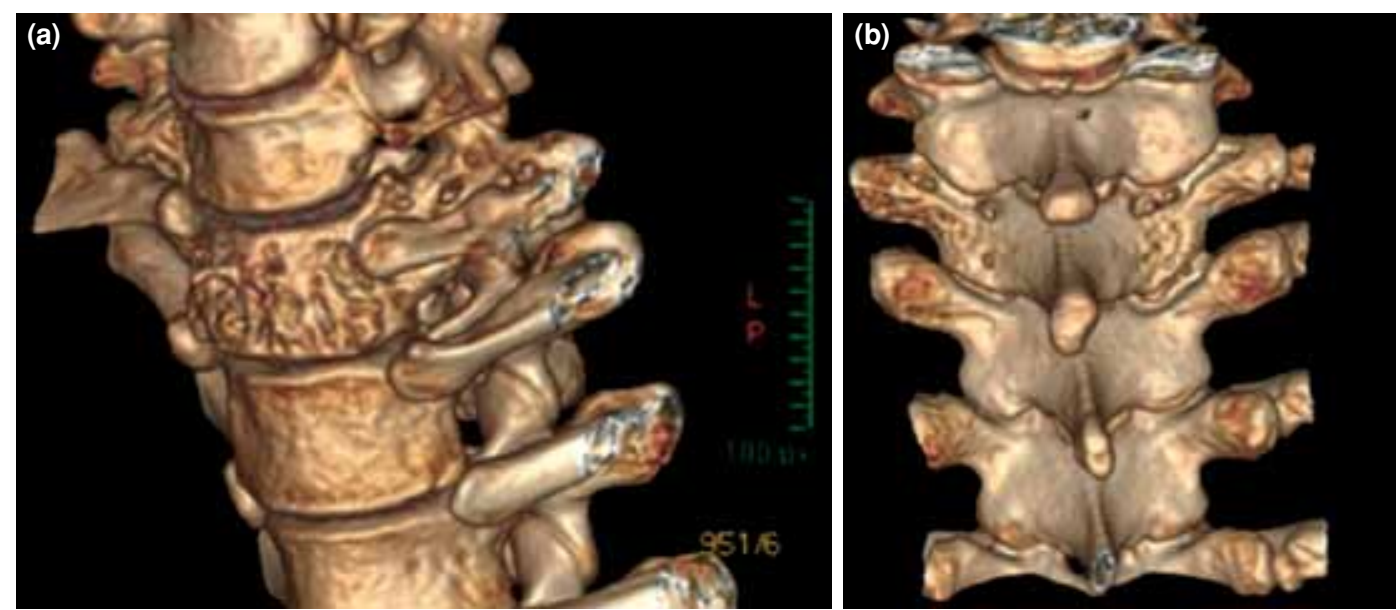

Figure 2. (a) The anterolateral and (b) posterior views of three-dimension computed tomography of cervicothoracic junction demonstrates involvement of entire $T_{1}$ vertebra.

The decision making process also involved a gynecologist, a radiotherapist, and an interventional radiologist. The final decision was to keep the patient lying in bed under corticoid treatment until the fetus maturity detected by ultrasound imaging and functional exams could allow performing a caesarian operation.

The patient accepted and was started $4 \mathrm{mg}$ intravenous betamethasone per day, weight bearing was not allowed, but motor rehabilitation program included active muscular exercises. At the $28^{\text {th }}$ week of pregnancy, angiography and embolization was performed, achieving $85 \%$ devascularization. On the following day, she was first submitted to a cesarean section under general anesthesia, and then cord decompression by laminectomy and transpedicular resection of the tumor followed by $\mathrm{C}_{4}-\mathrm{T}_{3}$ stabilization and fusion (Figure 4). The newborn was a male with excellent life parameters. The patient gradually started standing and walking exercises. Neurological status gradually improved. Six weeks after surgery, she received external beam conventional radiation therapy. At six months, she was ambulatory without assistance. Histopathological diagnosis had confirmed cavernous hemangioma.

At two-year follow-up, there is no evidence of local progression of the hemangioma, the neurological function is normal, and patient is fully ambulant and she returned back to work and social life. The child is fully normal.
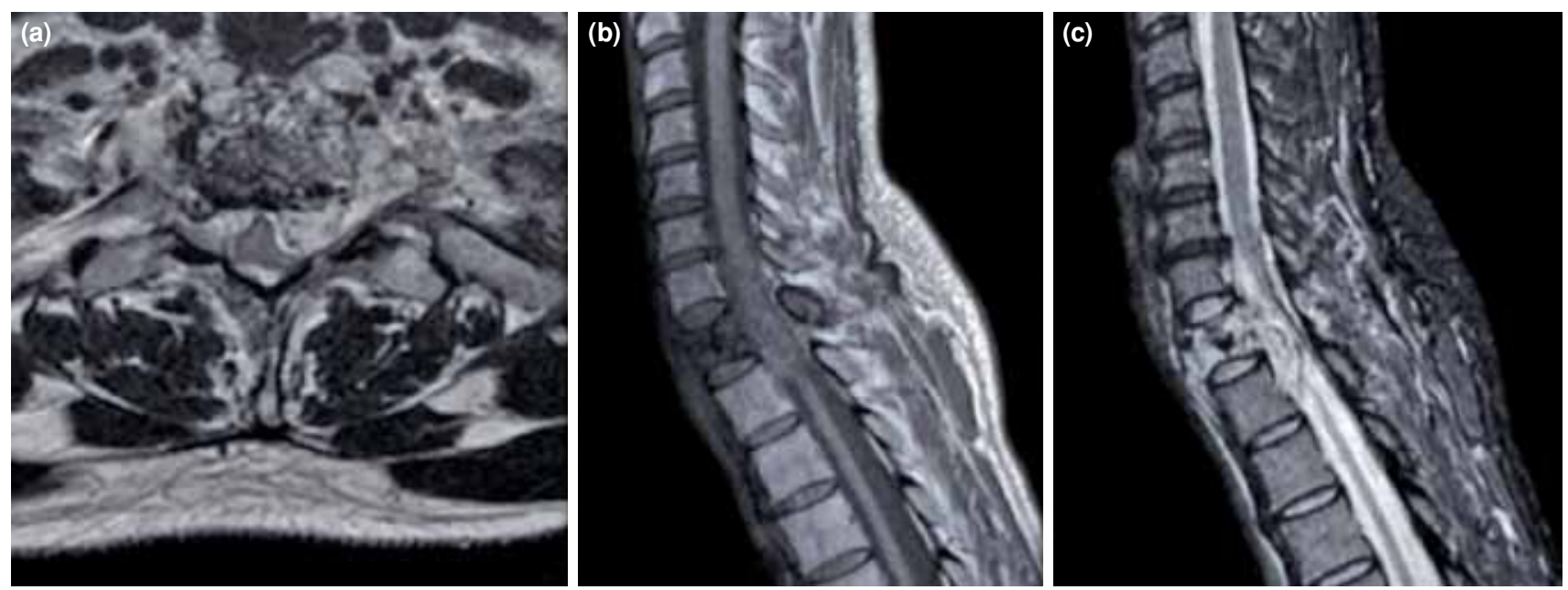

Figure 3. (a) Axial $\mathrm{T}_{2}$-weighted noncontrast-enhanced, (b) sagittal $\mathrm{T}_{2}$-weighted noncontrast-enhanced, and (c) sagittal $\mathrm{T}_{1}$-weighted magnetic resonance images of patient obtained preoperatively which were heterogeneously hyperintense demonstrate severe compression of spinal cord by epidural extension of tumor. 

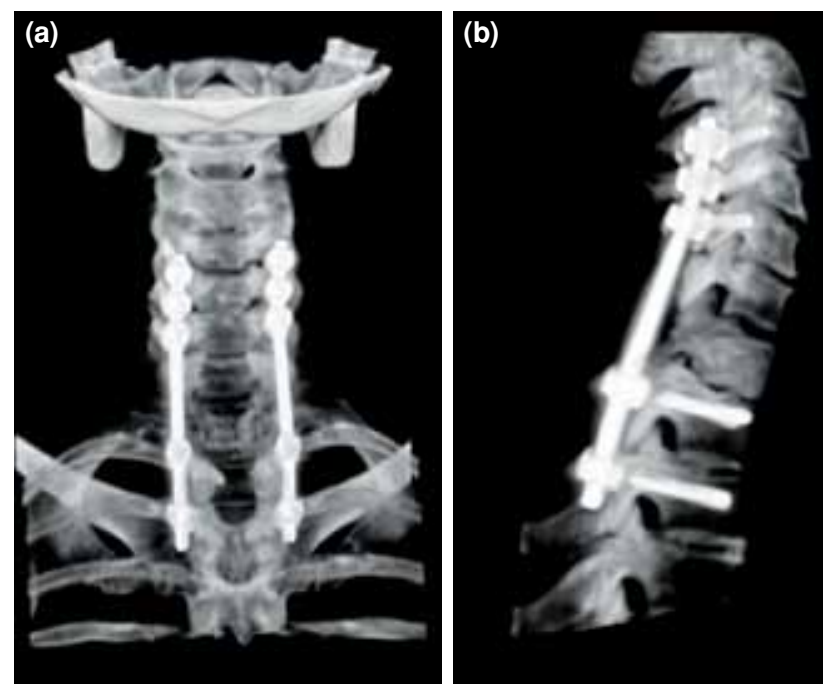

Figure 4. (a) Coronal and (b) sagittal postoperative computed tomography images show well decompressed and stabilized spine without any recurrence at two-year follow-up.

\section{DISCUSSION}

Vertebral hemangiomas are usually discovered incidentally; $10 \%$ to $12 \%$ of are reported to occur in a thoracic vertebra. ${ }^{[23]}$ The epidemiology, diagnostic characteristics, and management of these benign spinal neoplasms have been extensively discussed in the literature. ${ }^{[24-27]}$ The possibility of hemangiomas increasing in size, compressing the cord and reducing the vertebral body resistance during pregnancy or puberty is well known and is related to altered progesterone and estrogen levels and/or obstruction of paravertebral veins draining into inferior vena cava by gravid uterus. ${ }^{[28,29]}$ When hemangioma becomes symptomatic in a pregnant female, decisions related to timing and type of treatment are challenging due to the conflicting interests of neurological recovery (and treatment of pathologic or impending fracture) and fetus survival.

The case reported herein concerns a pregnant female complaining of pain and severe neurological problems at the $23^{\text {rd }}$ week. Patient refused to undergo emergency decompression which may expose the fetus to life risk mostly due to possible profuse bleeding while resection of the tumor. Cesarean operation at that time would as well end with the death of the fetus. Even if laminectomy could have been performed and pregnancy continued, the hemangioma would have been growing due to the continuity of hormonal activity. Radiotherapy alone was contraindicated for its teratogenic effect. The decision to delay decompressive surgery under corticoid treatment was also favored by the demonstrated association between exposures of low doses of betamethasone and accelerated fetal lung maturation. ${ }^{[30]}$ As soon as maturation was acceptably defined, cesarean operation and cord decompression were performed on the same day. Selective embolization the day before and radiotherapy after six weeks completed the treatment.

In conclusion, dealing with a complicated hemangioma in a pregnant female encompasses several issues: the risk of permanent paraplegia compared to the risk against the life of the fetus, increased risk of intraoperative profuse bleeding or radiation exposure of the fetus from $\mathrm{CT}$ scan during embolization or radiotherapy. A multidisciplinary approach included the spine surgeons discussing the case with a gynecologist, a pediatrician, an interventional radiologist, a radiotherapist, and obviously the patient and her family. The review of the literature for complicated hemangiomas in pregnancy revealed that vast majority of the cases had symptoms for several weeks or months. Emergency surgery can be delayed while keeping the patient under strict neurological observation, till the maturity of the fetus.

\section{Acknowledgements}

We thank to Mr. Stefano Boriani for his valuable editorial assistance.

\section{Declaration of conflicting interests}

The authors declared no conflicts of interest with respect to the authorship and/or publication of this article.

\section{Funding}

The authors received no financial support for the research and/or authorship of this article.

\section{REFERENCES}

1. Blecher R, Smorgick Y, Mirovsky Y. Symptomatic spinal hemangioma in pregnancy. Isr Med Assoc J 2010;12:311-3.

2. Tekkök IH, Açìkgöz B, Sağlam S, Onol B. Vertebral hemangioma symptomatic during pregnancy--report of a case and review of the literature. Neurosurgery 1993;32:302-6.

3. Schwartz TH, Hibshoosh H, Riedel CJ. Estrogen and progesterone receptor-negative T11 vertebral hemangioma presenting as a postpartum compression fracture: case report and management. Neurosurgery 2000;46:218-21.

4. Chi JH, Manley GT, Chou D. Pregnancy-related vertebral hemangioma. Case report, review of the literature, and management algorithm. Neurosurg Focus 2005;19:7.

5. Castel E, Lazennec JY, Chiras J, Enkaoua E, Saillant G. Acute spinal cord compression due to intraspinal bleeding from a vertebral hemangioma: two case-reports. Eur Spine J 1999;8:244-8.

6. Inamasu J, Nichols TA, Guiot BH. Vertebral hemangioma symptomatic during pregnancy treated by posterior decompression, intraoperative vertebroplasty, and segmental fixation. J Spinal Disord Tech 2006;19:451-4. 
7. Vijay K, Shetty AP, Rajasekaran S. Symptomatic vertebral hemangioma in pregnancy treated antepartum. A case report with review of literature. Eur Spine J 2008;17:299-303.

8. Kiroglu Y, Benek B, Yagci B, Cirak B, Tahta K. Spinal cord compression caused by vertebral hemangioma being symptomatic during pregnancy. Surg Neurol 2009;71:487-92.

9. Yuksel M, Yuksel KZ, Tuncel D, Zencirci B, Bakaris S. Symptomatic vertebral hemangioma related to pregnancy. Emerg Radiol 2007;13:259-63.

10. Shinozaki M, Morita A, Kamijo K, Seichi A, Saito N, Kirino T. Symptomatic T2 vertebral hemangioma in a pregnant woman treated by one stage combination surgery; posterior stabilization and anterior subtotal tumor resection. Case report. Neurol Med Chir (Tokyo) 2010;50:674-7.

11. Redekop GJ, Del Maestro RF. Vertebral hemangioma causing spinal cord compression during pregnancy. Surg Neurol 1992;38:210-5.

12. Liu CL, Yang DJ. Paraplegia due to vertebral hemangioma during pregnancy. A case report. Spine (Phila Pa 1976) 1988;13:107-8.

13. Schwartz DA, Nair S, Hershey B, Winkelman AC, Finkelstein SD. Vertebral arch hemangioma producing spinal cord compression in pregnancy. Diagnosis by magnetic resonance imaging. Spine (Phila Pa 1976) 1989;14:888-90.

14. Lavi E, Jamieson DG, Granat M. Epidural haemangiomas during pregnancy. J Neurol Neurosurg Psychiatry 1986;49:709-12.

15. Faria SL, Schlupp WR, Chiminazzo H Jr. Radiotherapy in the treatment of vertebral hemangiomas. Int J Radiat Oncol Biol Phys 1985;11:387-90.

16. Esparza J, Castro S, Portillo JM, Roger R. Vetebral hemangiomas: spinal angiography and preoperative embolization. Surg Neurol 1978;10:171-3.

17. Nelson DA. Spinal cord compression due to vertebral angiomas during pregnancy. Arch Neurol 1964;11:408-13.

18. Newman MJ. Spinal angioma with symptoms in pregnancy.
J Neurol Neurosurg Psychiatry 1958;21:38-41.

19. Fields WS, Jones JR. Spinal epidural hemangioma in pregnancy. Neurology 1957;7:825-8.

20. Askenasy H, Behmoaram A. Neurological manifestations in haemangioma of the vertebrae. J Neurol Neurosurg Psychiatry 1957;20:276-84.

21. Guthkelch AN. Haemangiomas involving the spinal epidural space. J Neurol Neurosurg Psychiatry 1948;11:199-210.

22. Bağatur AE, Yalçınkaya M. How to write a case report? or... not write at all? Eklem Hastalik Cerrahisi 2014;25:165-7.

23. Fox MW, Onofrio BM. The natural history and management of symptomatic and asymptomatic vertebral hemangiomas. J Neurosurg 1993;78:36-45.

24. McArthur N, Kasperk C, Baier M, Tanner M. 1150 kyphoplasties over 7 years: indications, techniques, and intraoperative complications. Orthopedics 2009;32:90.

25. Bandiera S, Gasbarrini A, De Iure F, Cappuccio M, Picci P, Boriani S. [Article in English, Italian] Symptomatic vertebral hemangioma: the treatment of 23 cases and a review of the literature. Chir Organi Mov 2002;87:1-15.

26. Acosta FL Jr, Dowd CF, Chin C, Tihan T, Ames CP, Weinstein PR. Current treatment strategies and outcomes in the management of symptomatic vertebral hemangiomas. Neurosurgery 2006;58:287-95.

27. Blecher R, Smorgick Y, Anekstein Y, Peer A, Mirovsky Y. Management of symptomatic vertebral hemangioma: follow-up of 6 patients. J Spinal Disord Tech 2011;24:196-201.

28. Lavi E, Jamieson DG, Granat M. Epidural haemangiomas during pregnancy. J Neurol Neurosurg Psychiatry 1986;49:709-12.

29. Edouard DA, Pannier BM, London GM, Cuche JL, Safar ME. Venous and arterial behavior during normal pregnancy. Am J Physiol 1998;274:1605-12.

30. Jobe AH, Nitsos I, Pillow JJ, Polglase GR, Kallapur SG, Newnham JP. Betamethasone dose and formulation for induced lung maturation in fetal sheep. Am J Obstet Gynecol 2009;201:611. 